Torsten Methling, Nina Armbrust, Thilo Haitz, Michael Speidel, Norman Poboss, Marina Braun-Unkhoff, Heiko Dieter, Brigitte Kempter-Regel, Gerard Kraaij, Ursula Schliessmann, Yasemin Sterr, Antje Wörner, Thomas Hirth, Uwe Riedel, Günter Scheffknecht, Power generation based on biomass by combined fermentation and gasification - A new concept derived from experiments and modelling, Bioresource Technology 169, 2014, 510-517.

The original publication is available at www.elsevier.com

http://dx.doi.org/10.1016/j.biortech.2014.07.036 


\section{Power Generation Based on Biomass by Combined Fermentation and Gasification - A New Concept Derived from Experiments and Modelling}

Torsten Methling ${ }^{\mathrm{a}, *}$, Nina Armbrust ${ }^{\mathrm{c}}$, Thilo Haitz ${ }^{\mathrm{d}}$, Michael Speidel $^{\mathrm{b}}$, Norman Poboss ${ }^{\mathrm{c}}$, Marina BraunUnkhoff $^{a}$, Heiko Dieter ${ }^{c}$, Brigitte Kempter-Regel ${ }^{e}$, Gerard Kraaii ${ }^{b}$, Ursula Schliessmann ${ }^{d}$, Yasemin Sterr $^{d}$, Antje Wörner ${ }^{b}$, Thomas Hirth ${ }^{d}$, Uwe Riedel ${ }^{a}$, Günter Scheffknecht $^{\mathrm{c}}$

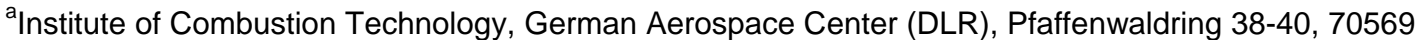
Stuttgart, Germany

${ }^{\mathrm{b}}$ Institute of Technical Thermodynamics, German Aerospace Center (DLR), Pfaffenwaldring 38-40, 70569 Stuttgart, Germany

'Institute of Combustion and Power Plant Technology, University of Stuttgart, Pfaffenwaldring 23, 70569 Stuttgart, Germany

Institute of Interfacial Process Engineering and Plasma Technology, University of Stuttgart, Nobelstrasse 12, 70569 Stuttgart, Germany

${ }^{\mathrm{e}}$ Fraunhofer Institute for Interfacial Engineering and Biotechnology, Nobelstrasse 12, 70569 Stuttgart, Germany

\section{Abstract}

A new concept is proposed for combined fermentation (two-stage high-load fermenter) and gasification (two-stage fluidised bed gasifier with $\mathrm{CO}_{2}$ separation) of sewage sludge and wood, and the subsequent utilisation of the biogenic gases in a hybrid power plant, consisting of a solid oxide fuel cell and a gas turbine. The development and optimisation of the important processes of the new concept (fermentation, gasification, utilisation) are reported in detail. For the gas production, process parameters were experimentally and numerically investigated to achieve high conversion rates of biomass. For the product gas utilisation, important combustion properties (laminar flame speed, ignition delay time) were analysed numerically to evaluate machinery operation (reliability, emissions). Furthermore, the coupling of the processes was numerically analysed and optimised by means of integration of heat and mass flows. The high, simulated electrical efficiency of $42 \%$ including the conversion of raw biomass is promising for future power generation by biomass.

*Corresponding author. Tel.: +49 7116862 277; fax: +49 7116862578.

E-mail address: torsten.methling@dlr.de 


\section{Keywords}

Decentralized power generation; Fermentation; Gasification; Hybrid power plant; Sewage sludge

\section{Introduction}

Presently, primary energy worldwide is mainly supplied by fossil fuels. Facing increasing energy demands and decreasing fossil fuel supplies, researchers need to target new sustainable concepts of energy conversion considering both resources and machinery. To fulfil future energy needs, the utilisation of biomass is an important element of prospective power generation.

Biomass as a renewable energy source has the potential to contribute to a major fraction of power generation without deforestation or competing with food production (Smeets et al., 2007), e.g. by the utilisation of by-products and residues of agriculture, forestry or food industry. In their worst case scenario, Smeets et al. (2007) predict a global biomass production above $40 \%$ of the global energy demands in 2050 (excluding transport and conversion losses). In areas with intense energy demands and/or high population densities like the US, EU or Japan they predict a lower corresponding biomass production, ranging from $10 \%$ to $20 \%$. In addition, compared to other renewable energies like wind and solar power, biomass can be stored for a continuous energy production, which can easily be adapted to flexible power demands. Therefore, biomass is an important element in global future power generation scenarios independent of the varying regional amount and availability of biomass.

However, one drawback of biomass is that it appears locally in small quantities and due to the low energy density, transportation is economically not feasible. Hence, small 
scale power generation units for biomass conversion are needed and required to run at high electrical efficiencies, to keep up with future primary energy demands. A key technology to achieve high electrical efficiencies is the solid oxide fuel cell (SOFC) (Santarelli et al., 2012; Tippawan and Arpornwichanop, 2014).

To develop such highly efficient units, the German Aerospace Center (DLR) and the University of Stuttgart propose a new concept of upgrading biomass to biogenic gas. It is based on fermentation and gasification as well as the subsequent utilisation in a hybrid power plant, consisting of an SOFC and a gas turbine (GT) (Fig. 1).

According to this new concept, wet biomass is fermented in a two-stage high load fermenter to biogas. Biogas production takes place in methanogenic mixed cultures where organic material is converted into methane in several reaction steps: Macromolecules like carbohydrates, fats and proteins are initially hydrolysed before being converted into organic acids and alcohols. These intermediates are transformed to acetic acid and ultimately to methane and $\mathrm{CO}_{2}$ in further reaction steps. The residues of the fermentation still contain unconverted thermochemical energy. Hence, the residues are dried and gasified together with additional wood in a fluidised bed gasifier to syngas. Small scale thermochemical biomass gasification is a suitable process to make use of this energy (Peng et al., 2012; Yan et al., 2010). Typical thermal fuel input for small scale fluidised bed gasification plants is around 10 MW (Hofbauer et al., 2003). A two stage gasification process was developed in order to achieve high conversion rates of these residues into a product gas with low tar concentration and high hydrogen product gas concentration up 80 vol.-\% $\%_{\mathrm{db}}$. In this process allothermal steam gasification is coupled with a water-gas shift reactor. In the water-gas shift reactor, the so called reformer, calcium oxide $(\mathrm{CaO})$ is used for $\mathrm{CO}_{2}$ capture in order to enhance the $\mathrm{H}_{2}$ concentration and reduce the $\mathrm{CO}$ and $\mathrm{CO}_{2}$ concentration. 
Before mixing and utilisation, the biogas and syngas must be cleaned (Aravind and de Jong, 2012; Woolcock and Brown, 2013). The requirements on the gas cleaning are more stringent for the SOFC than for the GT. The biogas requires only desulphurisation that can be accomplished by activated carbon. The syngas requires removal of tar ( $\mathrm{Li}$ and Suzuki, 2009), particles, sulphur, metals and halogens.

In the hybrid power plant an SOFC and a GT are coupled to utilise the product gases. In this configuration, the SOFC runs at elevated pressures (approximately 3 bar), increasing the electrical efficiency of the fuel cell (Henke et al., 2011). Since the SOFC cannot convert the entire fuel, the off-gas, still containing $\mathrm{H}_{2}$ and $\mathrm{CO}$, is burned in the GT. Even for small scale power generation electrical efficiencies above $50 \%$ are achieved by hybrid power plants, which are significantly higher compared to other conventional small scale power plants (Hohloch et al., 2008). The electrical efficiency of conventional small scale biomass plants (e.g. gasifier with gas engine) is around 30\% including the conversion of raw biomass (Dornburg and Faaij, 2001). Gas turbines of all performance rates, from a few $\mathrm{kW}$ up to hundreds of $\mathrm{MW}$, are economically in service. So far, SOFC have been accomplished in laboratory and pilot plant scale, but have not reached marketability. Whereas today SOFC plant sizes of approximately $100 \mathrm{~kW}$ are realised, SOFC plants have the potential to operate at several megawatts (Hohloch et al., 2008).

In the present work, the development, integration and optimisation of the important processes of the new concept (fermentation, gasification and the utilisation in a hybrid power plant, Fig. 1) are reported in detail. For the gas production process (fermentation and gasification) parameters were investigated by simulations and experiments to achieve high conversion rates of the biogenic material to biogas and syngas. For the utilisation of the product gas (biogas and syngas), important combustion properties 
(laminar flame speed, ignition delay time) were analysed numerically by validated chemical kinetic reaction mechanisms to assure a reliable operation with low emission levels for future application.

Furthermore, the processes (fermentation, gasification, utilisation) were profoundly analysed and optimised according to the integration of heat and mass flows and corresponding overall efficiencies were simulated. The synergies between the processes identified by the detailed research are a promising approach for future small scale biomass power application with high electrical efficiencies.

\section{Materials and Methods}

Each process within this project (fermentation, gasification, utilisation) was analysed, improved and adapted for the specific coupling considered within the new concept. According to each process, the focus of the analysis was set on different aspects: For the

(i) fermentation, on finding the right substrate, which could be converted at high rates and could provide enough residues for the subsequent gasification process; (ii) gasification, on the validation of the process and on achieving a high $\mathrm{H}_{2}$ content in the product gas for the utilisation; (iii) utilisation, on the combustion properties of the product gases and their consequences on machinery operation and emissions.

\subsection{Fermentation}

\subsubsection{Selection of Substrates}

Suitable biomasses are organic wastes which are characterised by fluidity and bioavailability. In addition, the availableness and disposability of biomass are important factors for the selection of a feedstock appropriate for large scale fermentation plants 
with several megawatts of power. Choosing the right feedstock decreases transport costs and hence raises the economic viability of the process. Therefore, the regional amount and availability of corn silage, fruit deposit from whole sale market and sewage sludge in Germany were verified and evaluated as follows.

Corn silage is produced most in Germany, compared to the other evaluated substrates. However, residues of corn silage are currently used for agriculture in Germany. For that reason they are presently not available for further treatment with gasification.

Nevertheless, the availability of corn silage residues for gasification could change due to altering regulatory framework, considering over-fertilisation. In that case, gasification of corn silage residues is a promising alternative. Also, the available amount of corn silage residues can be different in other countries. Thus the application of corn silage could be possible in Germany in the future or in other countries in the present. For that reason, fermentation characteristics of corn silage were analysed.

The composition of fruit and vegetable waste from the wholesale market varies substantially over the year. Seasonal variation of the substrate composition makes an effective substrate management and an intelligent process control indispensable. In Germany, a total of 770,000 t of fruit and vegetable waste was generated in 2009. There are 10 single collection points with a fruit and vegetable waste accumulation of 25,000 to $83,000 \mathrm{t} / \mathrm{a}$, which is enough for the operation of a large scale fermentation plant. However, the fruit and vegetable waste degradation level is larger than $90 \%$, resulting in insufficient amounts of digestion residues for gasification supply. Hence, no further fermentation experiments were carried out with fruit and vegetable waste as substrate. 
$1.9 \times 10^{6} \mathrm{t}$ dry mass of sewage sludge from municipal waste water plants accumulated in Germany in 2011 (Federal Ministry for the Environment, Nature Conservation and Nuclear Safety, 2013). 53\% were combusted, 30\% were brought into agriculture. The residues of sludge digestion contain $45-50 \%$ of the organic material of the raw sewage sludge according to about $50 \%$ of the total thermochemical energy of the untreated sewage sludge. Due to the fermentability of $50 \%$, with respect to the energy content of sewage sludge, there are enough digestion residues available for gasification.

For the reasons mentioned above, in the present work sewage sludge was chosen as feedstock for the large scale fermentation plant. Sewage sludge is the only feedstock, which can be accumulated in adequate amounts on site. Hence, these residues were used for the investigation of the overall process.

\subsubsection{Experimental Setup}

The process technology has to be conformed to each type of biomass. Degradation level, biogas composition and yield are dependent on the specific biomass. The purpose of this investigation was to enhance the biogas process with regard to high biogas yield corresponding to high degradation levels.

For fermentation corn silage and sewage sludge were chosen. The experiments with corn silage as substrate were performed in reactors with $1 \mathrm{l}$ working volume (batch). Sewage sludge was fermented in a two stage process (two reactors with $30 \mathrm{l}$ working volume). The reactors were operated at constant temperature $\left(37^{\circ} \mathrm{C}\right)$ and continuous blending. The pretreatment methods grinding and addition of trace elements were investigated for corn silage. Within the scope of the continuous experiments the fermentation characteristics of sewage sludge obtained from different wastewater plants were determined at various time periods. Also, fermentation parameters such as the 
hydraulic retention time (the ratio of the reactor volume to the volumetric flow infeed) were adjusted corresponding to the changing sewage sludge composition to achieve high degradation rates and biogas yields.

The substrates and the samples taken from the bioreactors were analysed in double determinations. For the substrates a range of the content of total solids (TS) and total volatile solids (TVS) are shown in Table 1. Furthermore, the effects of the organic concentration in the influent and the pretreatment of the waste were investigated, to increase the degradation level and biogas production.

\subsection{Gasification}

The principle of the gasification process is presented in Fig. 2. It consists of three reactors which include a gasifier and a reformer connected in series with regard to the gas flow and a regenerator (calciner). In the gasifier, the biomass is gasified under steam atmosphere in the temperature range from 800 to $850{ }^{\circ} \mathrm{C}$. Within this temperature range high biomass conversion and low tar concentration can be expected. The necessary heat for the endothermic gasification reactions is provided by the circulating $\mathrm{CaO}$ flow transferred to the gasifier from the regenerator, operating at a temperature above $900^{\circ} \mathrm{C}$. Subsequently, the gasifier product gas is fed into a reformer. The reformer is operating at a temperature range from $600{ }^{\circ} \mathrm{C}$ to $700{ }^{\circ} \mathrm{C}$. In this reactor, in situ adsorption of carbon dioxide takes place by the $\mathrm{CaO}$ sorbent through the carbonation reaction. Due to $\mathrm{CO}_{2}$ adsorption, the equilibrium of the water-gas shift reaction is shifted towards hydrogen. As a result of the improved fuel conversion in the gasifier due to the higher gasification temperature and the $\mathrm{CO}_{2}$ capture taking place in the reformer, the $\mathrm{H}_{2}$ content is increased to over 80 vol.- $\%_{\mathrm{db}}$ combined with high gas yield. Sufficient sorbent activity and reactor temperature levels are maintained in the reformer due to the Ca flow circulating in the regenerator-reformer loop. The regenerator heat 
requirements are covered through char originating from the gasifier and the combustion of directly fed biomass.

The investigation of the gasification process was divided into two steps: First, a simulation for the new biomass gasification process was developed using ASPEN Plus ${ }^{\mathrm{TM}}$ simulator. Aspen Plus ${ }^{\mathrm{TM}}$ process simulation software is widely used for biomass gasification modelling (de Jong et al., 2003; de Kam et al., 2009; Doherty et al., 2009; Sadhukhan et al., 2010; Tijmensen et al., 2002). This simulation software allows to perform total mass and energy balance calculations of the process. Thus, gas composition and gas yield were identified and a material and energy balance calculation was performed. With the help of this simulation the heat produced in the gasification process was determined for the integration into the overall process. The model of the gasification process was based on minimisation of Gibbs energy and some chemical reactions were restricted. The total thermal input of biomass (represented by wood pellets) was 17.4 MW. The input of the steam $\left(590^{\circ} \mathrm{C}\right)$ was $2.05 \mathrm{MW}$, the one of air $\left(850^{\circ} \mathrm{C}\right)$ was $2.65 \mathrm{MW}$. The temperatures in the gasifier, reformer and regenerator were set to $850^{\circ} \mathrm{C}, 650^{\circ} \mathrm{C}$ and $925^{\circ} \mathrm{C}$. The steam to carbon ratio (S/C) equalled 2 $\mathrm{mol}_{\mathrm{H} 2 \mathrm{O}} / \mathrm{mol}_{\mathrm{C}}$.

In the second step, the experimental investigation of the new gasification process was performed. Within these experiments, gas yield and gas composition, tar and water content in the product gas as well as tar composition at the outlet of the gasifier and the reformer were determined.

\subsection{Gas Utilisation}

For the combustion of the process gases (biogas, syngas and SOFC off-gas), combustion chambers need to be adapted or newly designed to assure a fuel flexible, 
reliable and secure operation with low emission levels. Therefore, in a first step, major combustion properties (ignition delay time and laminar flame speed) of the SOFC offgas were studied numerically and compared to the ones of a typical natural gas (92 mol\% $\mathrm{CH}_{4}, 8 \mathrm{~mol} \% \mathrm{C}_{2} \mathrm{H}_{6}$ ), the fuel that is used mostly in conventional gas power plants. This strategy allows checking the performance of current available detailed chemical kinetic models. Furthermore, the results may serve as a foundation for first combustion chamber designs, which provide a basis for more detailed designs derived with e.g. computational fluid dynamics (CFD) simulations, including the use of validated and efficient chemical kinetic models.

The calculations were performed at 3 bar, which is within the typical range of combustion pressures of a micro gas turbine. For the calculations, the detailed reaction models GRI 3.0 (Smith et al., 1999) and Petrova-Williams (Petrova and Williams, 2006), and in-house model called DLR-RG (Braun-Unkhoff et al., 2009) were used. Details of the mechanisms used for the calculations are given in Table 2.The mechanisms are developed, optimised and validated for the combustion of natural gas and/or syngas (Smith et al., 1999; Petrova and Williams, 2006; Braun-Unkhoff et al., 2009, 2012).

\section{Results and Discussion}

The processes (fermentation, gasification, utilisation) were investigated. The results of the processes were used for the heat and mass flow design and integration for the simulation of the overall process in 3.4. 


\subsection{Fermentation}

Experiments with corn silage were carried out in 11 laboratory biogas reactors in batch fermentation. Different pretreatment methods of corn silage (grinding and delignification) as well as the addition of trace elements to the methanogenic mixed culture enhanced the biogas production compared to unground corn silage.

It is shown that grinding of corn silage led to an increase of specific biogas production to approximately $650 \mathrm{l}_{\mathrm{STP}} / \mathrm{kg}_{\mathrm{TVS}}$ compared to $350 \mathrm{l}_{\mathrm{STP}} / \mathrm{kg}_{\mathrm{TVS}}$ for unground corn. Due to delignification an accelerated increase of the specific biogas production was achieved, whereas the final specific biogas production was not affected significantly. The maximum of $1070 \mathrm{l}_{\mathrm{STP}} / \mathrm{kg}_{\mathrm{TVS}}$ is attained by grinding of corn silage and addition of trace elements to the methanogenic mixed culture. In Fig. 3 the results for specific biogas production are shown for corn silage.

Sewage sludge from different wastewater plants obtained at various time periods were fermented in a two-stage high load fermenter to biogas. For the fermentation process a short hydraulic retention time of 11 days for the two stage plant with a high TVS degradation level of up to $50-55 \%$ was achieved. In the fermenter $80 \%$ of degradation took place in stage 1 . Biogas yield of $600 \mathrm{l}_{\mathrm{STP}} / \mathrm{kg}_{\mathrm{TV}}$ was achieved.

With increasing organic concentration in the reactor influent an increasing degradation rate was achieved for both stages. However, degradation level and degradation rate in stage 2 was below the corresponding values of stage 1 due to lower TVS concentration in the input of stage 2. On the other hand, the degradation rate also increases with increasing degradation level (Fig. 4). Simultaneously, the gas rate increased up to $4.5 \mathrm{l}_{\mathrm{STP}} /\left(\mathrm{l}_{\text {reactord }} \mathrm{d}\right)$. 
In Table 1, fermentation characteristics of suitable feedstock for small scale power generation applications are summarised.

\subsection{Gasification}

The simulation results of the process are shown in Table 3. High hydrogen concentration of 85.1 vol.- $\%_{\mathrm{db}}$ and low $\mathrm{CO}_{2}$ concentration of 2.3 vol.-\% $\%_{\mathrm{db}}$ were calculated. The lower heating value of the product gas was $14 \mathrm{MJ} / \mathrm{m}^{3}$ STP and the hydrogen yield $1.07 \mathrm{~m}^{3} \mathrm{STP} / \mathrm{kg}_{\text {fuel,daf }}$. The thermal output of synthesis gas is $9.75 \mathrm{MW}$. Due to the hot synthesis gas coming from the gasifier, the hot $\mathrm{CaO}$ flow and the exothermic $\mathrm{CO}_{2}$ adsorption, a heat release of 3.6 MW in the reformer was calculated. The flue gas of the regenerator was cooled down to $150{ }^{\circ} \mathrm{C}$ in order to avoid acid dewing. The product gas was kept at a temperature level of $650{ }^{\circ} \mathrm{C}$ for the hot gas cleaning.

The experimental results presented in this paper were obtained from an $8 \mathrm{~kW}_{\text {th }}$ lab scale facility consisting of two in series-connected bubbling fluidised bed reactors: a gasifier and a reformer. The facility is described in details elsewhere (Poboß et al., 2011). Since the small scale of the laboratory biogas reactor, no sufficient amount of sewage sludge residues was available. Therefore gasification experiments were performed with wood pellets. The raw wood pellets were characterised. They contained $46.6 \mathrm{wt} .-\%$ of carbon, 6.2 wt.- $\%$ of hydrogen and 41.1 wt.- $\%$ of oxygen. The ash content is 0.7 wt.- $\%$, the water content is 5.4 wt.- $\%$ and the lower heating value is $16.9 \mathrm{MJ} / \mathrm{kg}$. Table 3 shows the results of the batch experiments with wood pellets.

Gasification conditions were chosen similar to those in the simulation. The $\mathrm{H}_{2}$ concentration of 80 vol.- $\%_{\mathrm{db}}$ and the $\mathrm{H}_{2}$ yield of $1.24 \mathrm{~m}^{3} / \mathrm{kg}_{\text {fuel,daf }}$ is reached at $\mathrm{S} / \mathrm{C}=2.1$ $\mathrm{mol}_{\mathrm{H} 2 \mathrm{O}} / \mathrm{mol}_{\mathrm{C}}$ and a reformer temperature of $646^{\circ} \mathrm{C}$. Tar samples are taken following the 
Tar Guideline CEN/BT/TF 143 (2004) provided by the European Committee for Standardization. According to this guideline, the gas chromatography/mass spectrometry (GC/MS) tar concentration at the exit of the reformer is $4.7 \mathrm{~g} / \mathrm{m}^{3}$ STP and gravimetric tar concentration is $2.8 \mathrm{~g} / \mathrm{m}^{3} \mathrm{STP}$.

The results predicted by the simulation are in good agreement with experimental results. There are only small deviation comparing the results of ASPEN Plus ${ }^{\mathrm{TM}}$ simulation and the results from experimental investigation: The hydrogen concentration is a little overestimated and $\mathrm{CO}$ and $\mathrm{CO}_{2}$ concentration are little underestimated. This can be explained by non-equilibrium condition during the batch experiments which restricts $\mathrm{CO}_{2}$ adsorption and hydrogen production via water-gas shift reaction.

\subsection{Gas Utilisation}

The simulations of the combustion properties were conducted for the SOFC off-gas, consisting of $22.5 \mathrm{~mol} \% \mathrm{H}_{2}$, $4.4 \mathrm{~mol} \% \mathrm{CO}, 12.8 \mathrm{~mol} \% \mathrm{CO}_{2}$, and $60.3 \mathrm{~mol} \% \mathrm{H}_{2} \mathrm{O}$.

Results are shown in Fig. 5a (ignition delay time) and Fig. 5b (laminar flame speed). The calculated ignition delay times of the $\mathrm{H}_{2}$ rich SOFC off-gas are lower compared to the corresponding ignition delay times of the natural gas (see Fig. 5a). The lower ignition delay times are caused by the higher reactivity of the $\mathrm{H}_{2}$ molecules compared to $\mathrm{CH}_{4}$ (methane, natural gas).

In principle, shorter ignition delay times are beneficial for lower emission levels of unburned fuel because in the combustion chamber locally quenched gas has a higher probability to reignite for a complete combustion of the fuel, before leaving the reaction zone. However, the chance of a flashback is also increased which can lead to severe 
damage of turbo machinery. For this reason, shorter ignition delay times are unfavourable for premixed combustion systems.

The predicted laminar flame speeds of the hot SOFC off-gas (Fig. 5b) are much higher than the flame speeds of natural gas $\left(92 \mathrm{~mol} \% \mathrm{CH}_{4}, 8 \mathrm{~mol} \% \mathrm{C}_{2} \mathrm{H}_{6}\right)$ at conventional micro GT conditions (Fig. 5c). Due to the reactiveness (especially at high temperatures) and the low molecular mass of hydrogen $\left(\mathrm{H}_{2}\right)$, high contents of hydrogen result in high laminar flame speeds. On the other hand, high water $\left(\mathrm{H}_{2} \mathrm{O}\right)$ contents decrease laminar flame speeds, as water acts as a quencher in radical recombination reactions, thus leading to a reduced radical pool slowing down the overall reaction. Please note that it was therefore not possible to simulate laminar flames with the SOFC off-gas at $T_{0}=406 \mathrm{~K}$.

All reaction models used are optimised for the combustion of natural gas and/or syngas. Simulating combustion properties of a different fuel (in this case SOFC off-gas with high water content), can lead to errors predicting the combustion properties (see e.g. Braun-Unkhoff et al., 2012). To determine which model predicts the laminar flame speeds most accurate, sophisticated validation experiments are needed.

Turbulent flame speeds of practical flames of practical combustion processes correlate with laminar flame speeds (Griebel et al., 2007); thus, laminar flame speeds are an important indicator for the actual turbulent flames speeds found in practical applications. For higher flame speeds, the residence time of gases in the hot reaction zone is shorter, since the size of the reaction zone does not change or gets even smaller (Kuo and Acharya, 2012). Shorter residence times may offer some advantages, as for example this may lead to a reduction in $\mathrm{NO}_{\mathrm{X}}$ formation. However, higher flame speeds increase the risk of a flashback in premixed combustion systems. 
As seen in Fig. 5b, for a reduction of the flame speeds in technical combustion systems the SOFC off-gas should be burned very lean or mixed with cold oxidiser to reduce the inlet temperature of the combustion chamber.

In general, the ignition delay times and laminar flames speeds of natural gas predicted by the different models are in good agreement with each other. For the SOFC off-gas, there are significant deviations between the predictions of the different models (see Figs. 5a-c). The deviations in predicted ignition delay times and laminar flame speeds reveal the need for optimisation and experimental validation of the reaction models which is part of the on-going work - in order to allow for more precise calculations and predictions of combustion properties and more sophisticated CFD simulations for a detailed combustion chamber design.

\subsection{Overall Process}

Conversion of renewable energy like biomass and sewage sludge into electrical energy with a high efficiency requires the use of multiple conversion steps with a high level of integration of heat and mass flows.

With the results and expertise gained from the investigations 3.1. to 3.3., the processes were linked by means of heat and mass flows (Fig. 6). In the overall process sewage sludge with an energy flow of $10 \mathrm{MW}$ (large municipal sewage plant) is fermented and the residues are dried and fed into a biomass gasifier together with wood. The biogas from the fermentation and the syngas from the gasifier are cleaned, compressed, combined, and fed into a hybrid power plant consisting of an SOFC and a GT.

Using a two-stage fermentation process, approximately $50 \%$ of the energy of the sewage sludge is converted into biogas as stated in chapter 3.1. The fermentation waste, which contains $95 \%$ water, is first mechanically dehydrated to waste with $70 \%$ water 
content and then dried to $25 \%$ water content using waste heat from the process. This dried waste is fed to a two-stage fluidised bed gasifier together with wood and steam. In Fig. 6 the three reactors of the gasification process (compare Fig. 2) are illustrated as one process with input of wood (for the gasifier as well as for the regenerator) and sewage sludge (for the gasifier). Since the hybrid power plant section contains a gas turbine, the gases need to be compressed, which also increases the efficiency of the SOFC (Henke et al., 2011). For methane reformation and to prevent carbon formation in the SOFC, steam is required in the fuel gas. In the proposed process, the syngas from the gasifier is compressed at a temperature where the steam in the gas is not condensed. The advantage is that neither a condenser nor a steam generator is required, although at the cost of the need of doubling the power for compression (compare $P_{\mathrm{Compr}, \mathrm{BG}, \mathrm{b}}$ in Fig.6). The fuel is then fed to the fuel cell, as well as preheated compressed air. The operating conditions for the fuel cell were set to $700{ }^{\circ} \mathrm{C}$ as inlet temperature and $800{ }^{\circ} \mathrm{C}$ as outlet temperature. The low temperature gradient reduces thermal stresses within the SOFC, to avoid damages. The fuel utilisation was chosen in such a way that the temperature after subsequent burning of the depleted fuel and air was less than $1000{ }^{\circ} \mathrm{C}$ and that the temperature after the gas turbine was sufficient to preheat the air for the SOFC.

The simulations in Aspen Plus were based on the following assumptions:

- Gas composition of biogas: $60 \mathrm{~mol} \% \mathrm{CH}_{4}, 40 \mathrm{~mol} \% \mathrm{CO}_{2}$

- Drying of fermentation wastes from $70 \%$ to $25 \%$ water content with $0.85 \mathrm{kWh} / \mathrm{kg}$ water

- Cold gas efficiency of the two-stage gasification process: $56 \%$

- Air preheating and steam generation for the gasifier was covered by the gasifier flue gas. 
- Dry gas composition of gasification gas as shown in Table 3 (Simulation); $50 \mathrm{~mol} \% \mathrm{H}_{2} \mathrm{O} ; 440$ ppmv $\mathrm{C}_{10} \mathrm{H}_{8}$ (representing tar)

- Tar steam reforming was performed at $900^{\circ} \mathrm{C}$

- $\quad$ The SOFC fuel utilisation is $63 \%$ at a mean cell voltage of $0.75 \mathrm{~V}$

- Isentropic efficiency of gas turbine: $85 \%$ and compressor: $78 \%$

- $\quad$ The pressure at the gas turbine was $3 \mathrm{bar}$

- Heat losses (in heat exchangers, gas cleaning, SOFC, turbine etc.) were neglected

As required at low temperature, heat demand for drying fermentation wastes (compare $Q_{1}$ at Fig. 6) can be covered by waste heat from the off-gas of the gas turbine $\left(Q_{2}\right)$. Yet extra heat for the tar reformer is required. With the assumptions mentioned, the electrical efficiency for the integrated and combined process was calculated as followed:

$\eta_{\mathrm{el}}=\frac{P_{\mathrm{SOFC}}+P_{\mathrm{Turb}}-P_{\mathrm{Compr}, \mathrm{BG}, \mathrm{a}}-P_{\mathrm{Compr}, \mathrm{BG}, \mathrm{b}}}{Q_{\text {SewageSludge }}+Q_{\mathrm{Wood}}+Q_{3}}=\frac{(6.17+4.24-0.04-0.39) \mathrm{MW}}{(10+12.4+1.27) \mathrm{MW}}=42.2 \%$

Due to the internal heat required for the drying of the sewage sludge, the heat available for external applications like district heating is reduced. Using the heat above $80{ }^{\circ} \mathrm{C}$ for district heating or other low temperature heating applications, the heat efficiency can be calculated by:

$\eta_{\text {heat }}=\frac{Q_{2}-Q_{1}+Q_{4}+Q_{5}}{Q_{\text {Sewagesludge }}+Q_{\text {Wood }}+Q_{3}}=\frac{(5.34-3.38+3.1+0.39) \mathrm{MW}}{(10+12.4+1.27) \mathrm{MW}}=23.0 \%$

The maximum total efficiency increases to $65.2 \%$. 
The sewage sludge energy input flow of $10 \mathrm{MW}$ represents a large sewage plant for a population of about 500,000. The corresponding gasifier of $17.4 \mathrm{MW}$ is a relatively small gasifier. The 6.1 MW SOFC is much larger than the largest SOFC plants demonstrated so far, which are in the $100 \mathrm{~kW}$ range. For the SOFC plant, multiple stacks with a power level in the $10 \mathrm{~kW}$ range is foreseen. A $4.2 \mathrm{MW}$ gas turbine is state of the art.

\section{Conclusions}

In the present work, an innovative process chain was identified for an efficient decentralised power generation: The coupling of large scale sewage sludge fermentation with small scale gasification with $\mathrm{CO}_{2}$ separation and the subsequent utilisation of the biogenic gases in a hybrid power plant. The analysis and integration of the heat and mass flows of the process chain resulted in a simulated electrical efficiency of $42 \%$, considerably higher compared to conventional applications. The analysis of the utilisation process illustrates the need of fuel flexible combustion chambers, due to the variety of fuel compositions being burned at different operating points.

\section{Acknowledgement}

The grant of Helmholtz Gemeinschaft within the project DLR@UniST is gratefully valued. The funding of the Ministerium für Wissenschaft, Forschung und Kunst and the Ministerium für Finanzen und Wirtschaft of the federal state of Baden-Württemberg is thankfully acknowledged. 


\section{References}

1. Aravind P.V., de Jong W., 2012. Evaluation of high temperature gas cleaning options for biomass gasification product gas for Solid Oxide Fuel Cells. Prog. Energy Combust. Sci. 38, 737-764.

2. Braun-Unkhoff M., Slavinskaya N.A., Aigner, M, 2009. Detailed and reduced reaction mechanism of biomass-based syngas fuels. Proceedings of GT2009, ASME Turbo Expo, Orlando, USA, GT2009-60214.

3. Braun-Unkhoff M., Herzler J., Herbst J., Kick T., Naumann C., Riedel U., 2012. Alternative Fuels Based on Biomass: An Investigation of Combustion Properties of Product Gases. Proceedings of GT2012, ASME Turbo Expo, Copenhagen, Denmark, GT2012-69282.

4. de Jong W., Ömer Ü., Jans A., Klaus R.G.H., Hartmut S., 2003. Biomass and fossil fuel conversion by pressurized fluidised bed gasification using hot gas ceramic filters as gas cleaning. Biomass Bioenergy 25, 59-83.

5. de Kam M.J., Vance Morey R., Tiffany D.G., 2009. Biomass Integrated Gasification Combined Cycle for heat and power at ethanol plants. Energ. Convers. Manage. 50, 1682-1690.

6. Doherty W., Reynolds A., Kennedy D., 2009. The effect of air preheating in a biomass CFB gasifier using ASPEN Plus simulation. Biomass Bioenergy 33, 11581167.

7. Dornburg V., Faaij A.P.C., 2001. Effciency and economy of wood-fired biomass energy systems in relation to scale regarding heat and power generation using combustion and gasification technologies. Biomass Bioenergy 33, 91-108.

8. Federal Ministry for the Environment, Nature Conservation and Nuclear Safety, 2013. http://www.bmu.de/themen/wasser-abfallboden/abfallwirtschaft/statistiken/klaerschlamm/, 12/10/13. 
9. Griebel P., Siewert P., Jansohn, P., 2007. Flame characteristics of turbulent lean premixed methane/air flames at high pressure: Turbulent flame speed and flame brush thickness. Proc. Comb. Inst. 31, 3083-3090.

10. Henke M., Kallo J., Friedrich K.A., Bessler W.G., 2011. Influence of pressurisation on SOFC performance and durability: A theoretical study. Fuel Cells 11, 581-591.

11. Hofbauer H., Rauch R., Bosch K., Koch R., Aichernig C., 2003. Biomass CHP plant Güssing - A success story, in: A.V. Bridgwater (Ed.), Pyrolysis and Gasification of Biomass and Waste, CPL Press, Newsbury, UK, pp. 371-383.

12. Hohloch M., Widenhorn A., Lebküchner D., Panne T., Aigner M., 2008. Micro gas turbine test rig for hybrid power plant application. Proceedings of GT2008, ASME Turbo Expo, Berlin, Germany, GT2008-50443.

13. Kuo K.K.Y., Acharya R., 2012. Applications of turbulent and multi-phase combustion. John Wiley \& Sons, Hoboken, NJ.

14. Li C., Suzuki K., 2009. Tar property, analysis, reforming mechanism and model for biomass gasification - An overview. Renew. Sust. Energ. Rev. 13, 594-604.

15. Peng L., Wang Y., Lei Z., Cheng G, 2012. Co-gasification of wet sewage sludge and forestry waste in situ steam agent. Bioresour. Technol. 114, 698-702.

16. Petrova M.V., Williams F.A., 2006. A small detailed chemical-kinetic mechanism for hydrocarbon combustion. Comb. Flame 144, 526-544.

17. Poboß N., Armbrust N., Zieba M., Scheffknecht G., 2011. Staged biomass gasification with insitu $\mathrm{CO}_{2}$ capture for hydrogen maximation. Proc. of the 11nd Int. Conf. on Polygen. Strategies, Vienna, Austria.

18. Sadhukhan J., Zhao Y., Shah N., Brandon N.P., 2010. Performance analysis of integrated biomass gasification fuel cell (BGFC) and biomass gasification combined cycle (BGCC) systems. Chem. Eng. Sci. 65, 1942-1954. 
19. Santarelli M., Barra S., Sagnelli F., Zitella P., 2012. Biomass-to-electricity: Analysis and optimization of the complete pathway steam explosion - enzymatic hydrolysis - anaerobic digestion with ICE vs SOFC as biogas users. Bioresour. Technol. 123, 430-438.

20. Smeets E.M.W., Faaij A.P.C., Lewandowski I.M., Turkenburg W.C., 2007. A bottom-up assessment and review of global bio-energy potentials to 2050. Prog. Energy Combust. Sci. 33, 56-106.

21. Smith G.P., Golden D.M., Frenklach M., Moriarty N.W., Eiteneer B., Goldenberg M., Bowman C.T., Hanson R.K., Song S., Gardiner Jr. W.C., Lissianski J., and Qin Z., 1999. GRI 3.0 mechanism, version 3.0, http://www.me.berkeley.edu/gri_mech, $1 / 19 / 2014$

22. Tijmensen M.J.A., Faaij A.P.C., Hamelinck C.N., van Hardeveld M.R.M., 2002. Exploration of the possibilities for production of Fischer Tropsch liquids and power via biomass gasification. Biomass Bioenergy 23, 129-152.

23. Tippawan P., Arpornwichanop A., 2014. Energy and exergy analysis of an ethanol reforming process for solid oxide fuel cell applications. Bioresour. Technol. 157, 231239.

24. Woolcock P.J., Brown R.C., 2013. A review of cleaning technologies for biomassderived syngas. Biomass Bioenergy 52, 54-84.

25. Yan F., Luo S., Hu Z., Xiao B., Cheng G., 2010. Hydrogen-rich gas production by steam gasification of char from biomass fast pyrolysis in a fixed-bed reactor: Influence of temperature and steam on hydrogen yield and syngas composition. Bioresour. Technol. 101, 5633-5637. 


\section{Figure Captions}

Fig. 1. Scheme of the biomass conversion and power generation process.

Fig. 2. Structure and process scheme of the biomass gasification with $\mathrm{CO}_{2}$ separation. Fig. 3. Course of biogas production for different pretreatments and supplementation of corn silage in batch fermentation.

Fig. 4. Total volatile solids degradation rate $\left(\mathrm{g}_{\mathrm{TVS}} / \mathrm{l}_{\text {working volume }} \mathrm{d}^{-1}\right)$ as a function of total volatile solids degradation level (\% $\%_{\text {TVS-input }}$ of stage 1 resp. stage 2 ) of sewage sludge in a two stage plant.

Fig. 5. Predicted (a) ignition delay times of natural gas and the SOFC off-gas in air, and predicted laminar flame speeds of (b) the SOFC off-gas and (c) natural gas in air.

Fig. 6. Scheme of the overall process and energy flows for the conversion of sewage sludge and wood. 


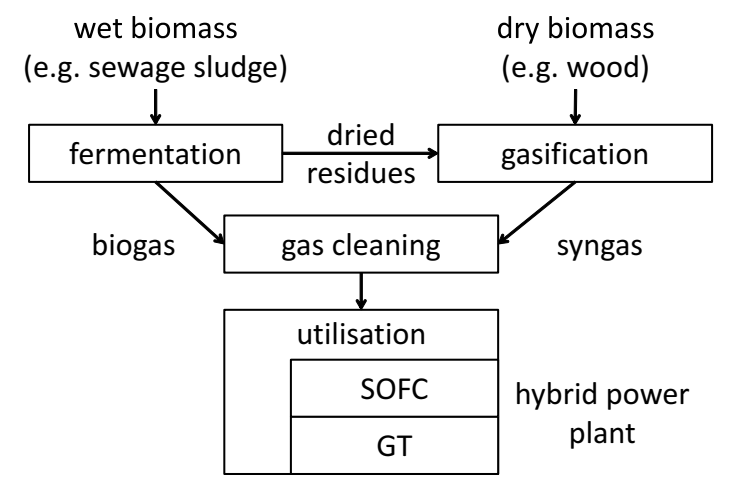

Fig. 1. Scheme of the biomass conversion and power generation process. 


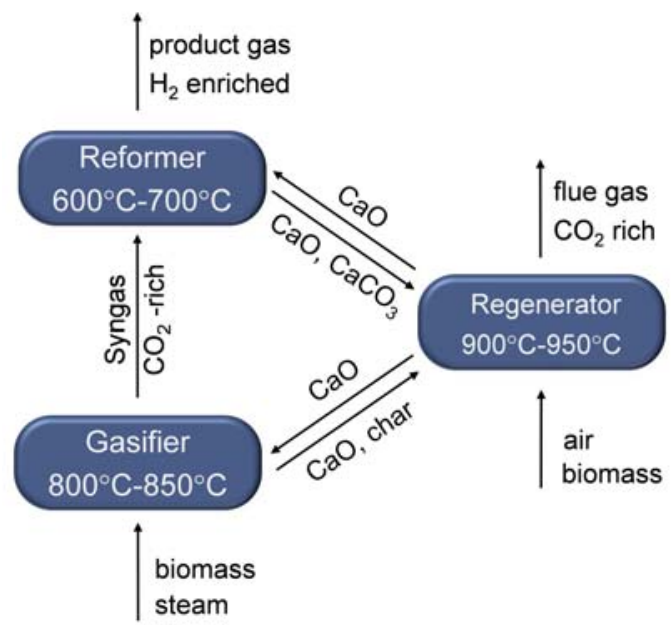

Fig. 2. Structure and process scheme of the biomass gasification with $\mathrm{CO}_{2}$ separation. 


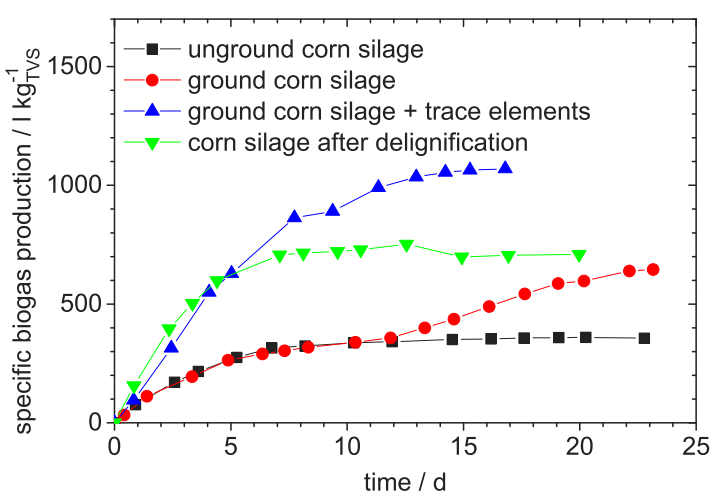

Fig. 3. Course of biogas production for different pretreatments and supplementation of corn silage in batch fermentation. 


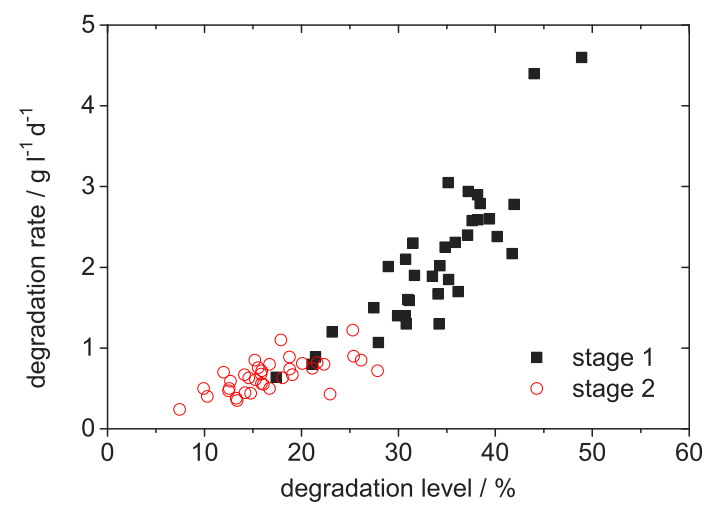

Fig. 4. Total volatile solids degradation rate $\left(g_{T V S} / l_{\text {working volume }}{ }^{-1} d^{-1}\right)$ as a function of total volatile solids degradation level (\%Tvs-input of stage 1 resp. stage 2) of sewage sludge in a two stage plant 
(a)

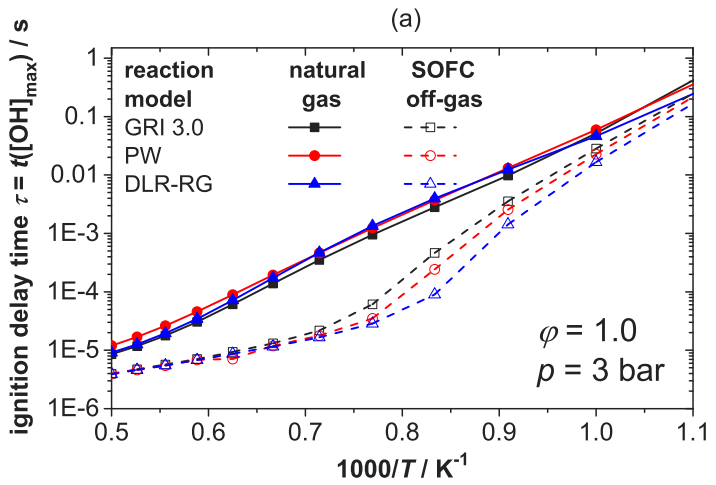

(b)

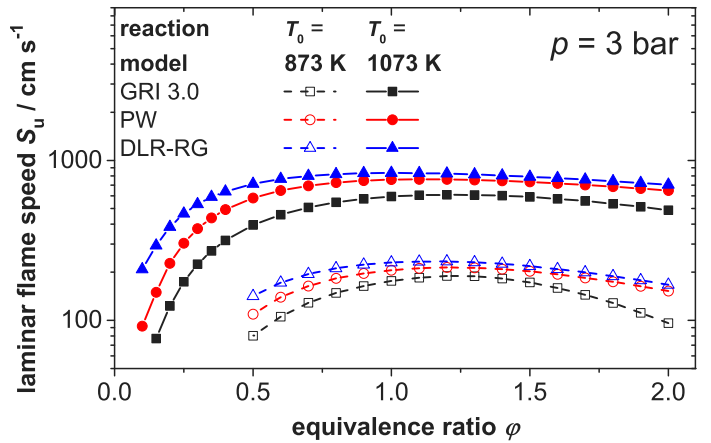

(c)

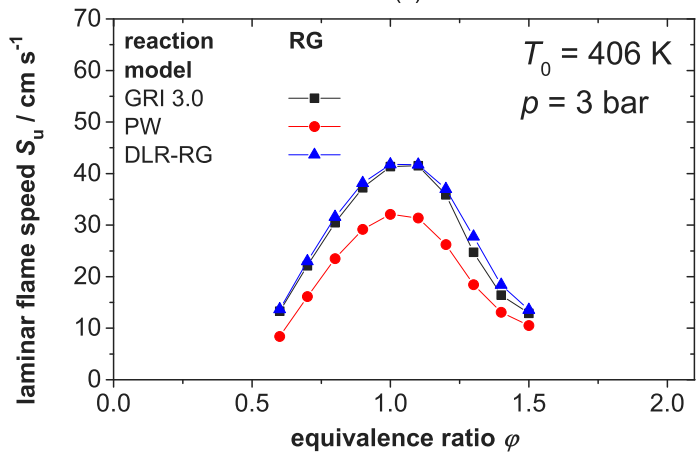

Fig. 5. Predicted (a) ignition delay times of natural gas and the SOFC off-gas in air, and predicted laminar flame speeds of (b) the SOFC off-gas and (c) natural gas in air. 


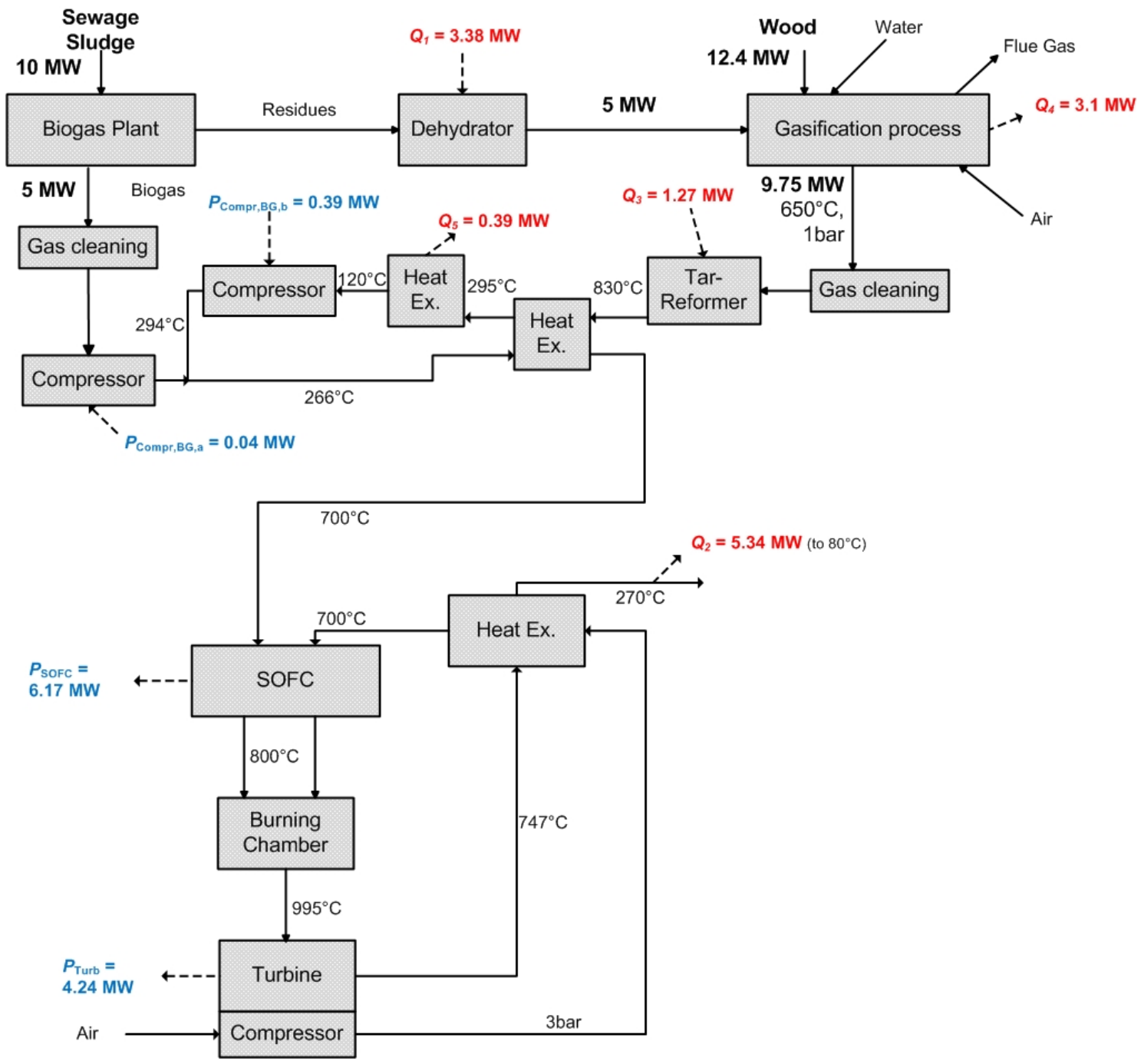

Fig. 6. Scheme of the overall process and energy flows for the conversion of sewage sludge and wood. 


\section{Table 1}

Fermentation characteristics and various parameters of corn silage and sewage sludge.

\begin{tabular}{|c|c|c|}
\hline Parameter & $\begin{array}{l}\text { Corn } \\
\text { silage }\end{array}$ & $\begin{array}{l}\text { Sewage } \\
\text { sludge }\end{array}$ \\
\hline $\begin{array}{l}\text { TS-content } \\
{[\%]}\end{array}$ & $\begin{array}{l}26.9- \\
12.9\end{array}$ & $2.8-7.0$ \\
\hline $\begin{array}{l}\text { TVS-content } \\
\text { [\%] }\end{array}$ & $\begin{array}{c}25.8- \\
12.1\end{array}$ & $2.0-5.1$ \\
\hline $\begin{array}{l}\mathrm{CH}_{4} \text {-content } \\
\text { [vol.-\%] }\end{array}$ & 55 & 60 \\
\hline $\begin{array}{l}\mathrm{CO}_{2} \text {-content } \\
\text { [vol.-\%] }\end{array}$ & 45 & 40 \\
\hline $\begin{array}{l}\text { Biogas yield } \\
{\left[\mathrm{l}_{\mathrm{STP}} / \mathrm{kg}_{\text {TVS }}\right]}\end{array}$ & 1070 & 600 \\
\hline $\begin{array}{l}\text { Hydraulic } \\
\text { retention time } \\
\text { [d] }\end{array}$ & Batch & 11 \\
\hline $\begin{array}{l}\text { Amount Germany } \\
{\left[10^{6} \mathrm{t} / \mathrm{a}\right]}\end{array}$ & 71 & 1.9 \\
\hline $\begin{array}{l}\text { Thermal capacity } \\
\text { [GW] }\end{array}$ & 1.3 & 1.0 \\
\hline $\begin{array}{l}\text { Fermentability } \\
{[\%]}\end{array}$ & 70 & 50 \\
\hline
\end{tabular}


Table 2

Details on the reaction models used for the calculations.

\begin{tabular}{llcc}
\hline Reference & Name & \#Species & \#Reactions \\
\hline Smith et al., 1999 & GRI 3.0 & 53 & 325 \\
Petrova and Williams, 2006 & PW & 44 & 235 \\
Braun-Unkhoff et al., 2009 & DLR-RG & 65 & 359 \\
\hline
\end{tabular}




\section{Table 3}

Simulation and experimental results of the gasification process.

\begin{tabular}{|c|c|c|}
\hline Parameter & Simulation & Experiment \\
\hline $\mathrm{H}_{2}$ [vol.- $\% \mathrm{db}$ ] & 85.1 & 80.4 \\
\hline CO [vol.-\% $\left.\%_{\mathrm{db}}\right]$ & 2.0 & 4.7 \\
\hline $\mathrm{CO}_{2}\left[\right.$ vol.--\% $\left.\%_{\mathrm{db}}\right]$ & 2.3 & 6.2 \\
\hline $\mathrm{CH}_{4}\left[\right.$ vol. $\left.-\%_{\mathrm{db}}\right]$ & 8.3 & 6.8 \\
\hline $\mathrm{C}_{\mathrm{x}} \mathrm{H}_{\mathrm{y}}$ [vol.- $\left.\%_{\mathrm{db}}\right]$ & 2.3 & 1.8 \\
\hline $\begin{array}{l}\text { Gas yield } Y \\
{\left[\mathrm{~m}^{3}{ }_{\text {STP }} / \mathrm{kg}_{\text {fuel,daf }}\right]}\end{array}$ & 1.26 & 1.54 \\
\hline $\begin{array}{l}\text { Synthesis gas } \\
\text { output [MW] }\end{array}$ & 9.75 & - \\
\hline $\begin{array}{l}\text { Heat reformer } \\
{[\mathrm{MW}]}\end{array}$ & 3.55 & - \\
\hline $\begin{array}{l}\text { Heat flue gas } \\
\text { regenerator } \\
{[\mathrm{MW}]}\end{array}$ & 4.55 & - \\
\hline
\end{tabular}

